\title{
A Study of Buddhist Bhaktism with Special Reference to the Esoteric Buddhism
}

\section{Norio SEKIDO}

The Sanskrit term bhakti is most often translated into English as "devotion," and it has been mentioned Bhaktimārga especially in the Bhagavadgita, the "path of devotion," is understood to be one major type of Hindu spiritual practice. One can define that bhakti is the divine-human relationship as experienced from the human side. ${ }^{1)}$ The bhaktimārga is a path leading toward liberation (mokșa) from material embodiment in our present imperfect world and the attainment of a state of abiding communion with a personally conceived ultimate reality. ${ }^{2)}$

Modern historical approaches to Indian religion generally recognize some traces of bhaktism in a few of the Vedas and the classical Upanișads also and see it strikingly present in large sections of the epics including notably the Bhagavadgi $\bar{t} \overline{\bar{a}} .{ }^{3)}$

The present writer admits the historical process of bhaktism, which are primitive, early, middle and later bhaktism respectively. ${ }^{4)}$

Deep significance was attached to bhakti (devotion, faith, sincerity). Faith in Buddhism is expressed with the terms (śraddhā, adhimukti, prasāda and bhakti). Of these, prasāda is peculiarly Buddhistic. Faith appears in the form of purified mind (pasanna-citta); the unity of faith and wisdom is characteristic of Buddhist belief ${ }^{5}$.

Bhakti, as mentioned earlier, which conveys the meaning of "difinately devotional faith" came to be used more frequently with the lapse of time ${ }^{6}$.

Although the term bhakti is seldom mentioned in Buddhist literature, we can find the influence of bhaktism in buddhist belief. The evidences 
represent in the Pāli Cannon, King Ashoka's Inscriptions, Nāgārjuna's the Vigrahavyāvartanī, Yaśomitra's the Abhidharmakoṣabhāsya and so on.

The original concept of faith in the Pure Land Sutras was not a devotional one (bhakti), but faith in teachings (śraddhā), which is highly different from faith taught by later chinese and japanese Pure Land Buddhists. It is preached the benefits of faith in the Amitābha Buddha, who is a dharmakāya. This faith must be related to Buddhist Bhaktism ${ }^{7)}$.

It is the pure and tranquil state of mind (prasāda) that is emphasized in the Pure Land Sutras. A stūpa-worship may be related to the Buddhist Bhaktism which the Saddharmapundarika-sütra recommends in the 11 th chapter $^{8)}$.

In the Mahāyāna Buddhism, Gautama Buddha loses his human character and is endowed with superhuman powers. The Jätakas of Theravāda give place to the Avadānas or the glorious achievement of Buddha and his followers. So far as the Esoteric Buddhism concerned, there is practically nothing to distinguish it from the religion of Hinduism ${ }^{9}$.

On the Esoteric Buddhism, let us listen to Benoytosh Bhattacharya ${ }^{10}$. According to him, the Buddhist Tantras in outward appearance resemble the Hindu Tantras to a marked degree but in reality there is very little similarity between them, either in subject matter or in philosophical doctorines inculcated in them, or in religious principles. This is not to be wondered at, since the aims and objects of the Buddhists are widely different from those of the Hindus. He is right. For instance, it is the Mahāvairocana-sūtra,

tad etat sarvajña-jñānaṃkaruṇā-mūlam bodhicitta-hetukam upāyaparyavasānam iti $^{11)}$

We say Vajrayāna "Diamond Vehicle", later called Tantric Buddhism also, is Esoteric Buddhism. This is highly sophysticated Buddhism. There are the Mahāvairocana-sūtra, the Diamond Peak Sutra, Prajñāpāramitānaya or Adhyardhaśatikā Prajñāpāaramitā (Eng. The Reason Essence Sutra) and so on.

The point is the great antiquity and consistent development of Tantric 
tendencies in Buddhism. Already the Early Mahāsanghikas had a special collection of mantric formulas in their Dhārañi-pitaka, and the Mañjuśrimülakalpa, which according to some authorities goes back to the first century A.D., contains not only mantras and dharanis, but numerous mandalas and mudras as well. But for even if the dating of Mañjuśrimülakalpa is somewhat uncertain, it seems probable that the Buddhist Tantric system had crystallized into a definite form by the end of the third century A.D., as we see from the well-known Guhya-samaja (Tib. dpal-gsang-hdus-pa) Tantra. In the Hevajra Tantra, idạ̣ jñānaṃ mahāsūkṣmaṃ vajramaṇụaṃ nabhopaman/ virajaskam mokṣadam săñam pitā te tvam asi svayam//4 $4^{12} / /$

And the Diamond Peak Sutra says to us

kathạ̣ kulaputānuttarāṃ samyaksaṃbodhim abhisambhotsyase yas tvaṃ sarvatathāgatatattvānabhi jñatayā sarvaduhkarāny utsahasi.

It is mentioned about the truth in all the tathagatas. All the tathagatas sit on the bodhimanda and they preach the truth before Sarvarthasiddhi who attains in the asphanakasamadhi. And also it is said in the Diamond Peak Sutra,

'Oṃ yathā sarvatathāgatā tathāham'/

Om, I am that all the tathăgatas are//

According to Śankara, bhakti means rather then much more sophysticated intellectual. His works form the foundation of all Saivaite philosophy, made use of ideas of Nāgārjuna and his followers to such an extent that orthodox Hindus suspected him of being a secret devotee of Buddhism. In a similar way the Hindu Tantras, too, took over the methods and principles of Buddhist Tantrism and adapted them to their own purposes much as the Buddhists had adapted the age-old principles and techniques of yoga to their own systems of meditation. This view is not only held by Tibetan tradition and confirmed by a study of its literature, but has also been verified by Indian scholars after a critical investigation of the earliest Sanskrit texts of Tantric Buddhism and their historical and ideological relationship with the 
Hindu Tantras.

Therefore the Hevajra Tantra, satya-satya-parivarta, chap. 5

vajrạ̣ ḍombì bhaven mudrā padmạ̣ nartī tathaiva ca/

karma rajakī samākhyātā brāhmaṇi ca tathāgatìi/6//

ratnaṃ caṇụalinī jñeyā pañcamudrā viniścitā/

But this tantra said earlier,

idaṃ jn̄ānaṃ mahāsūkṣmaṃ vajra maṇ̣am nabhopamam/

virajaskam mokṣadam pitā to tvam asi svayam//

Those who express a devotion of passionate attachment to the supremebeing, especially when the supreme-being is conceived as Krishna, Vishnu, Buddha, are sometimes dissatisfied with merely spiritual union after this earthly life. They yearn for the supreme-being's physical embraace of their present embodied selves. Bhaktas differ as to whether such union of the human devotee's body with the supreme-being's body is possible. Within this life, however, ecstatic moments of perceived union are fleeting. Permanent union brings with it an end to the bhakta's life in this world, as is dramatically portrayed in the stories of the merger of two of the Tamil Vail Vaiṣnava saints Antal and Tiruppan Alvar into the supreme-being's image incarnation, Ranganatha. Similar stories are told of the Rajpat woman saint Mira Bai, absorbed with Krishna's image at Dvark, and of Caitanya, who, according to the local Oriya tradition in Puri, was absorbed into the image of Jagannatha.

To understand an alien experience we need to remember partially similar experiences familiar to us. Bhakti has both appealed to and puzzled non-indian people because they see in its central features Western monotheism combined with other elements that seem different or even totally alien. Many features of Hindu bhakti are also found in the more popular aspects of Jainism and Buddhism, and Pure Land Buddhism has incorporated much of bhakti at its very core.

We may show you good example connected to Buddhist Bhaktism, it is called the Bhakti-sataka. This consists of lo7 verses, which is the only extant Buddhist work extolling devotional faith related to Bhaktism, 
particularly the Later Bhaktism which the present author called earlier paper.

In this work Sri Rama Candrabharati (c.1200-1250), criticized the popular faith in Siwa, Vishnu, Brahmā etc. It is likely that Buddhist rivival in Srilanka has something to do with this poetical work.

1) Jadnath Sinha, "Bhagavata religion: the cult of Bhakti", culturl Heritage of India, vol. IV, Calcutta 1956 (reprint), p. 146 S.N. Dasgupta "Hindu Mysticism"

2) R.G. Bhandarkar, "Vaisnavism, Saivism and Minor Religious Systems", Varanasi 1965 (reprint), p. 28. Śvetāśvatara Upanișad, Íśa Upanișad.

3) Mircea Eliade, “Encyclopaedia of Religions”, 'Bhakti', pp. 130-134., Krishna Sharma, "Bhakti and the Bhakti Movement", 1987, pp. 109-129.

4) E.W.Hopkins, "The Epic Use of Bhagavat and Bhakti", Journal of the Royal Asiatic Society, 1911, pp. 727-738., Minoru Hara, A Study of Bhakti”, Nihonbukkyogakkai-nenpo 28, 1962, pp. 1-24.

5) Kotatsu Fujita, "Hokkaido Daigaku Bungakubu Kiyo", No.6, pp. 67f, Zenno Ishigami in IBK (Indogaku Bukkyogaku Kenkyu), vol. 8, No. 2, March 1960, pp. 79-86. , Akinobu Watanabe, Buddhist Seminar, No.13, May 1971, pp. 51-68.

6) Loyalty (bhakti, sneha, anuraga) to Lords in India, discussed by Minoru Hara, Suzuki Nenpo, No. 8, 1971, pp. 70-88.

7) Name-mysticism or the archaic belief in name can be found in other traditions also as Mantra-yoga in Hinnduism, Dhikr in Mohammedanism, Philokaklia in the Eastern Church.

8) Stūpa-worshipping must be related to Bhaktism,

9) Sir Charles Eliot, "Hinduim and Buddhism", vol. III, London, 1954., E.J. Thomas, "History of Buddhist Thought", London, 1933.

10) Benoytosh Bhattacharya, "An Introduction to Buddhist Esoterism", 1932, p. 47.

11) Kamalaśila's quotations, Shunkyo Katsumata, "Japanese Development of the Esoteric Buddhism”, Shunju-sha, 1970.

12) Shin'ichi Tsuda, “Anti-Esoteric Buddhism”, 1987, p. 249.

〈Key Wards〉 Buddhist Bhaktism, Hindu Bhaktism, Mahāvairocana-sūtra, Diamond Peak Sutra, Esoteric Buddhism Śraddhā

(Research Fellow, The Eastern Institute., Ph.D.) 